\title{
A Fenomenologia do Espírito e o seu conteúdo real
}

Tran Duc Thao*

DOI 10.20399/P1982-999X.2016v1n1pp155-180

I

Apenas a imensidão da influência de Hegel pode ser comparável ao mistério que envolve os textos hegelianos. A dialética aparece como uma magia cujo segredo não parece haver sido encontrado por nenhum comentador. Se, o conceito se apresenta como saber de si, esse saber permanece como um em-si que não se tornou ainda um para-nós.

Desde este ponto de vista, é apreciável a publicação por Raymond Queneau do célebre curso de Alexandre kojève sobre a Fenomenologia do Espírito ${ }^{l}$. Pela primeira vez nos encontramos frente a uma explicação efetiva que confere ao texto um sentido concreto relacionando-o a fatos reais. Desde o vir-a-ser da consciência de si Marx, havia reconhecido o movimento da história humana: faltava mostrar o conteúdo em detalhe. $\mathrm{O}$ comentário de kojève nos eferece um ensaio de rara lucidez e de profunda originalidade.

O motor da dialética se apresenta em Hegel como uma força misteriosa, a potência do negativo, que assimila o objeto ao sujeito e faz passar cada momento ao seu contrário. Kojève o interpreta ao modo de Marx, como a negatividade real: o desejo e o trabalho negando o dado natural e transformando-o de maneira a retorná-lo humano. A mediação é a atividade que permite ao homem fazer independente das condições imediatas e a elevar-se à universalidade num mundo que ele mesmo tem elaborado.

Porém, o desejo e o trabalho não designam ainda nada mais que a relação exterior do homem em face da natureza. A negação não recebe seu sentido espiritual senão como negação de si. $\mathrm{O}$ homem se nega a si mesmo num desejo particular à espécie humana, o desejo do desejo ou o desejo de reconhecimento, que o conduz a arriscar voluntariamente sua vida numa luta por puro prestígio, para demonstrar-se como independente da existência animal e digna de ser reconhecida. O resultado imediato é a morte de um dos adversários. Porém, tal negação é abstrata e suprime as condições de um reconhecimento efetivo. O vencido deve permanecer vivo para reconhecer seu vencedor: um transforma-se no senhor e o outro no escravo.

\footnotetext{
*"La Phenomenologie de l'esprit et son contenu reel" in Les Temps Modernes 36 (1948), 493519.Tradução de Danilo Vaz-Curado R. M. Costa, Professor da UNICAP/PE, email : danilo@unicap.br. ${ }^{1}$ Alexandre Kojève, Introduction à la lecture de Hegel.
} 
O senhor atinge a existência propriamente humana negando em si mesmo a existência animal mediante a luta de vida ou morte: o escravo, é reduzido ao momento da coisa. Porém a humanidade do senhor permanece sendo imediata, posto que conduz a uma existência ociosa. O escravo submetido ao trabalho, realiza pelo fato mesmo dessa violência as condições de uma liberação efetiva. Porém o homem não é verdadeiramente humano senão quando arriscou sua vida para afirmar o sentido. A história do trabalho e das lutas pelo reconhecimento definem o vir-a-ser histórico como vir-a-ser humano.

A dialética da Fenomenologia não faz mais do que reproduzir, segundo Kojève, esse movimento real. O primeiro mundo propriamente histórico é o mundo grego, onde os senhores passavam seu tempo na política e na guerra, deixando o trabalho efetivo para seus escravos. Porém o imperialismo romano realiza uma nivelação geral, mediante a submissão de todos a um único. Os velhos escravos persuadiam-se de que haviam tornado-se realmente livres, forjando ideologias que colocam a liberdade fora da situação real: o estoicismo, o ceticismo e o cristianismo.

Uma liberação desse gênero é ilusória, o escravo não arriscou usa vida numa luta por reconhecimento. O Cristianismo não realiza a igualdade entre os homens senão ao custo de uma servidão comum. O Escravo, liberando-se do senhor humano, se torna escravo do senhor divino, escravidão devida ao mesmo motivo que a anterior: o medo da morte, sublimado desta vez no desejo de uma vida eterna. A liberação verdadeira consistirá segundo Kojève, em negar a existência de Deus aceitando a ideia da morte, o que não é possível senão numa sociedade universal e homogênea, onde todos possam ser reconhecidos. Tal reconhecimento satisfaz o homem concedendo-lhe a sua existência a plenitude de sua significação, fazendo inútil a ideia de um além. Todo o movimento do mundo cristão consiste em realizar as etapas pelos quais o homem consegue a sua satisfação. É precisamente o resultado que se obtém com Napoleão, com quem termina a história, e Hegel que explica sua significação.

É impossível reproduzir a riqueza de análises concretas que fazem o mérito do raro comentário de Kojève. Por trás da aspereza de um texto abstruso, o interprete descobre um conteúdo ao mesmo tempo objetivo e vívido, de uma assombrosa profundidade e de um realismo surpreendente. Ademais, parte-se de um ponto de vista 
cuja solidez não dá lugar a discussão: a dialética hegeliana apenas tem sentido na perspectiva do ateísmo. Como fez notar Henri Niel "ninguém em nossa época pode negar a admitir que o pensamento de Hegel termine por despojar de seu sentido religioso os dogmas cristãos"2.

Faremos evidentemente mais reservas sobre o trabalho de realização: nos parece exagerado querer interpretar o conteúdo da Fenomenologia inteiramente pela dialética do senhor e do escravo. Sem dúvida, a história é feita de lutas e do trabalho humano. Porém esses conceitos são demasiadamente vagos e não dá conta das particularidades do movimento, tal como Hegel o expôs. A relação de dominação à aquela de servidão, tal como tem observado o próprio Kojève ${ }^{3}$, não explica o reconhecimento recíproco dos indivíduos no interior da totalidade social, que define a concepção hegeliana da espiritualidade. As figuras fenomenológicas, como figuras do espírito, escapam quase completamente à interpretação proposta. Assim, a cidade antiga que implica evidentemente o momento da escravidão se caracteriza em sua estrutura espiritual pela oposição entre família e Estado, das potências subterrâneas e das divindades da luz: não há aqui dominação, nem servidão, senão cisão interna na comunidade de homens livres. A dialética que conduz à unidade do mundo, sob o império romano permanece também no mistério, as guerras tinham tantas oportunidades de perpetuar as divisões como de suprimi-las. O caso do cristianismo pode parecer mais favorável, posto que seria o medo à morte que havia feito do cristão o escravo de Deus. Porém, é fácil ver que uma explicação deste gênero revela um racionalismo abstrato, do tipo da Aufklãrung. Enfim, se a dialética do mundo da alienação, desde a Idade Média à Revolução pode definir-se a grosso modo como a libertação do escravo cristão, faz-se dificilmente explicável por um conceito tão geral o detalhe das figuras que balizam o movimento e ainda menos sua gênese concreta. Numa palavra, se as noções de luta e de trabalho parecem caracterizar a realidade histórica em seu conjunto, elas aparecem como formais desde que se as aplica, como quer Hegel, à diversidade de conteúdos. Resulta uma certa desigualdade no comentário: as figuras da consciência (Capítulo I a III) tem sido, em particular, relativamente abandonadas: seria difícil, com efeito, explicá-las seguindo o esquema do senhor e do escravo.

O formalismo somente é o signo da abstração. O conceito fundamental de reconhecimento se encontra separada, no comentário de Kojève, de todo o

\footnotetext{
${ }^{2}$ Henri Niel "L'interpretation de Hegel", in Critique, Nov. 1947, p. 430.

${ }^{3}$ A. Kojève, Hegel, Marx et le cristianisme, in Critique, ago/set, 1946, p. 353.
} 
desenvolvimento anterior: ele define ainda o princípio da separação como dualidade absoluta e totalmente explicável do homem e da natureza. O Animal não pode desejar mais que objetos e permanece desse modo o mesmo sobre o plano do objeto. O Homem deseja o desejo, põe voluntariamente sua vida em perigo numa luta de puro prestígio, para demonstrar-se como independente da existência biológica. Nesta negação de si como simples ser natural, o homem realiza a consciência de si [Selbstbewusstsein], enquanto que o animal apenas possui o sentimento de si [Selbstgefühl].

A cisão seria, portanto total e faria do surgimento da humanidade um começo absoluto. Porém, a dialética, tal como a compreende Hegel, consiste precisamente em identificar as contradições e fazer emergir a diferença no seio da unidade. A dualidade da natureza e do espírito implica uma dupla passagem, como o vir-a-ser-humano da natureza e o vir-a-ser-natural da ideia, onde cada termo se realiza negando-se em seu oposto. Kojève condena-a, sem um amplo exame, como o erro monista de Hegel. Ao mesmo tempo se encontram refutados os princípios clássicos do marxismo. Porém, de fato, não se eliminou simplesmente o materialismo: se recusou toda a dialética em geral, em sentido hegeliano. A repugnância de Kojève pelo monismo seria justificável, se trata-se de afirmar a identidade abstrata de natureza e espírito. Porém, ninguém ignora que toda a obra de Hegel tenha sido escrita para protestar contra tal interpretação. A verdadeira identidade implica nela a negação e a diferença, como identidade da identidade e da não-identidade.

No desenvolvimento a consciência de si, no capítulo IV da Fenomenologia, é ainda que seja assim, de uma continuidade perfeita: o biológico e o humano são dois momentos de um mesmo e único vir-a-ser. As noções de desejo do desejo e de luta por puro prestígio não existem em nenhuma parte, que saibamos da obra de Hegel. Enquanto a oposição da consciência em si e do sentimento de si, não aparece ao menos no texto em questão, onde o autor fala uniformemente da consciência de si [Selbstbewusstsein]. Trata-se, com efeito, da gênese do Si a partir da natureza.

O objeto se define ao fim do movimento da consciência como infinidade, ou, unidade cindindo-se em si mesma e como identidade na oposição. Enquanto que a diferença é somente uma, porém, se encontra imediatamente suprimida, o objeto não é já oposto ao sujeito, senão que vem a ser idêntico, como o si que se aparece a si mesmo: a consciência enquanto consciência do objeto tornou-se consciência de si. A infinitude se apresenta então sob dois aspectos: como subjetividade, é o desejo que suprime a alteridade do objeto e o apropria; como objetividade, é o movimento mesmo da vida, 
como totalidade de formas independentes que apenas se mantêm, em sua existência, separadas apenas pela atividade mesma pela se comprometem num processo universal de ação recíproca. Desde o ponto de vista exterior, os seres viventes se alimentam uns dos outros, o ato pelo qual cada um conserva sua existência individual somente é a efetivação de um movimento universal. Do ponto de vista interior, o movimento aparece como subjetividade desejante, niilizando o outro e assimilando-o a si. A consciência é consciência do objeto como idêntico a si: é consciência de si. Porém, a vida e o desejo apenas superam a separação de modo imediato: terminam de fato na reprodução e na proliferação de existências individuais. A consciência desejante perpetua a alteridade negando-se sobre o modo natural: "Ela faz a experiência da independência do objeto". Em razão desta independência, o objeto não será verdadeiramente o $S i$ e a consciência si senão quando o outro se nega a si mesmo: "A consciência de si apenas consegue sua satisfação através de outra consciência de Si”.

Tal movimento se realiza quando o vivente se choca com outro vivente, que responde a seu ataque atacando-o. "A consciência de si é ser-para-si igual a si mesmo excluindo de si tudo o que é outro [...] O outro aparece como um objeto inessencial, marcado com o caráter do negativo. Porém o outro é também uma consciência de si. Um indivíduo surge frente a frente com outro indivíduo. Surgindo assim imediatamente, não são um para o outro senão simples objetos, figuras independentes, consciências fundidas no ser e na vida; porém, o objeto se determinou aqui como vida" ${ }^{4}$. Um ser vivente encontra outro ser vivente e cada um percebe o outro como uma simples presa a destruir. O movimento é recíproco; cada um buscando a morte de outro, põe sua própria vida em perigo, se nega a si mesmo negando seu adversário. Assim se compromete sobre o fundamento do desejo biológico - o desejo de suprimir o outro e de absorvê-lo uma luta de vida ou morte, de onde o ser vivente se constitui como independente da vida justamente pela afirmação desta própria vida. Na exasperação da animalidade, cada um se nega como existência animal e percebe o outro como negando-se a si mesmo. Ao Suprimir o objeto sua própria objetividade, a consciência de si já não o toma como outro senão como idêntico a si ou um outro-de-si-mesmo. A luta de vida ou morte quando se realiza, sob sua forma imediata, o reconhecimento das consciências de si, como transição da natureza ao espírito, não se motiva, pois pela intervenção de um elemento radicalmente novo, o desejo do desejo, que não está em questão, por outra

\footnotetext{
${ }^{4}$ Phänomenologie des Geistes, Edition Hoffmeister, p. 143. Trad. De J. Hyppolite, I, p. 158.
} 
partem, em Hegel. Ela somente mostra como seu momento supremo, a vida opondo-se a vida e transformando-se precisamente na negação da natureza sua própria realização.

A vida e a consciência de si definem as duas faces da existência do ser vivente, como objetividade e subjetividade. Na luta desenvolve-se uma cisão que termina numa pretensão mais desenvolvida; ao vencedor se reserva o momento da consciência de si e o vencido encontra-se reduzido à vida corporal. Se sente a tentação de realizar mais uma vez a separação absoluta, o Si aparecendo como pura negação da existência biológica. Todavia, está na essência da dialética demonstrar a identidade em sua maior oposição e a exposição da Fenomenologia o faz com total claridade.

Contrariamente às aparências, o vencido, aceitando a servidão, não renunciou a consciência de si, posto que retrocedeu ante a morte precisamente porque tendo compreendido, na angústia, que a vida não é uma simples condição exterior, senão a realidade mesma de Si. "Esta consciência provou a angústia, não com respeito a tal ou qual coisa, nem durante tal ou qual instante, senão com respeito à totalidade de sua essência, pois sentiu o medo da morte, o senhor absoluto. Nessa angústia, se dissolveu intimamente, tremeu nas profundidades de si mesma, e tudo o que estava fixo vacilou nela. Porém, tal movimento puro e universal, tal fluidificação absoluta de toda a subsistência é a essência simples da consciência de si, a absoluta negatividade, o puro ser-para-si que é assim nessa consciência". ${ }^{5}$ Assim, o Si se descobrira diante da morte num ser efetivo. Na angústia, todo o constituído se desmorona para pôr-se em sua plenitude ao ser-para-si como existência pura e fluidez absoluta. Essa existência se revela como a própria vida, o vencido não se limitou ao corpo como a uma coisa, senão como à realidade mesma do si, como a negatividade absoluta e pura ser-para-si. Se a experiência do escravo é profundamente humana e se o medo da morte constitui a premissa de uma verdadeira formação, é porque a morte desvelou o ser da consciência de si em sua verdade original, como existência material: "a consciência refutada em si mesma" se revelou como pura dialética do corpo ou negatividade vivente. Nesta perspectiva, o trabalho não forma, por assim dizer, a partir de fora, senão em sua existência a mais íntima: "a forma pelo fato de ser exteriorizada, não torna-se para a consciência que trabalha um outro que ela: pois, essa forma é precisamente seu puro ser-para-si que se eleva assim a partir dela à verdade". 6 O Si somente se realiza autenticamente a si mesmo porque é reconhecido como corporal na angústia, e se tem

${ }^{5}$ Phänomenologie des Geistes, Edition Hoffmeister, p. 148. Trad. De J. Hyppolite, I, p. 164.

${ }^{6}$ Phänomenologie des Geistes, Edition Hoffmeister, p. 149. Trad. De J. Hyppolite, I, p. 165-166. 
efetivamente elevado à universalidade pelo serviço e pela trabalho. O Senhor apenas possui uma liberdade aparente, pois sua vitória somente tem sido uma negação imediata, em última instância, animal, do ser-aí natural: por isso, continua vivendo no desejo e no prazer. O Escravo, chegará à uma libertação efetiva porque se descobriu como objeto e se formou em sua realidade objetiva.

O capítulo IV da Fenomenologia parece apresentar a luta das consciências de $\mathrm{Si}$ em seu sentido mais geral, como contradição imanente à essência mesma da vida. Vêem-se exemplos característicos no mundo da natureza: assim, o combate do tigre e da píton. Porém, a plena significação apenas se revela sob a forma propriamente humana. Enquanto motiva a constituição do espírito. Um resultado deste gênero apenas é possível desde o fundamento de uma atividade econômica, e os textos de Iena conferem sobre este ponto, todas as precisões desejáveis. A luta de vida ou morte se compromete numa defesa dos bens acumulados, na economia natural, na família. O reconhecimento é reconhecimento da posse que se constitui em propriedade: a família é superada na sociedade civil.

O homem sai da vida propriamente animal quando se põe a produzir suas próprias condições de existência. ${ }^{7}$ Esta produção sob sua forma imediata se desenvolve no quadro da comunidade natural ou familiar. A família e os bens produzidos pelo trabalho de seus membros constituem a primeira totalidade que permite suprassumir a existência imediata. Enquanto o animal supera realmente o objeto no desejo e o gozo, a relação de posse mantém a coisa negando-a em sua exterioridade. Por meu trabalho, faço do objeto um bem que disponho. O real é absorvido em mim, subsistindo em sua realidade objetiva: eu o sinto, fora de mim, como um movimento de mim mesmo. A exterioridade enquanto negada e conservada, define a existência ideal, ou, existência na consciência. Pela produção familiar se constitui a primeira forma do mundo como humano, disponível para o homem, da consciência como consciência humana, enquanto que implica o objeto nela a título de sentido dirigido como objeto intencional.

Porém, a relação de posse se revela imediatamente como dialética. A totalidade familiar cujo conteúdo, já é humano, permanece em sua forma sobre o plano da natureza: cada família, como totalidade orgânica, exclui necessariamente as outras. O conflito é inevitável. Não poderá limitar-se a tal ou qual bem em dissenso, pois o bem, enquanto possuído pelo $\mathrm{Si}$, é assimilado a seu ser-mesmo e todo o golpe dado a uma

\footnotetext{
${ }^{7}$ Jenenser Realphilosophie, I, p. 220.
} 
parte, será sentido como tal pelo todo. "É como totalidades desse gênero que dois adversários se enfrentam, é como tal que querem reconhecer-se e saber-se reconhecidos. Devem, portanto, atacar-se reciprocamente: pois, é numa ação real que cada um deve afirmar a singularidade de sua existência como totalidade exclusiva. A violência é necessária." ${ }^{8}$ Assim as famílias que se colocam em guerra desejam fazer-se reconhecer não como puras consciências de si independentes da existência natural, mas como totalidades reais. O Si apenas é a unidade ideal de seu corpo e seus bens, e se se compromete numa luta total não o faz por puro prestígio, mas porque desde a posse de seus bens, alcança a si mesmo em sua totalidade: as noções de prestígio e de honra apenas designam esta totalidade como unidade imediata do ser-aí natural. Todavia, a situação experimentará uma reviravolta no combate e o Si se demonstra como o contrário do que acreditava ser. "Apenas posso conhecer-me como essa totalidade singular na consciência do outro me colocando em sua consciência como uma totalidade que exclui e persegue sua morte, Enquanto persigo sua morte, me exponho a própria morte, arrisco minha vida. Me coloco numa contradição: quero afirmar meu ser e meus bens como existência singular e esta afirmação passa a seu contrário, isto é, sacrifico todos os bens e a possibilidade de todo bem e de todo gozo, a própria vida. Afirmando-me como totalidade de uma existência singular, me suprassumo precisamente como tal. Quero ser reconhecido nesta extensão de minha existência, em meu ser e meus bens, porém obtenho o oposto, posto que suprimo esta existência.... Esse reconhecimento das existências singulares é assim a absoluta contradição em si mesma." 9

Através desta dialética na qual a natureza se nega afirmando-se, o econômico passa ao político. É a defesa de interesses materiais que põe o homem numa luta de onde por uma consequiência inesperada se revela como independente de seus próprios interesses. Reconhecido como pura consciência de si torna-se uma pessoa e a comunidade natural ou familiar alcança existência espiritual na totalidade social. A consciência "efetua em si mesma esta reflexão que a totalidade singular (natural ou familiar) querendo manter-se como tal suprassume absolutamente a si mesma e faz o contrário do que pretende. Apenas pode existir suprassumida, não manter-se como um ente, senão apenas como um ser que se põe suprassumido e não pode ser reconhecido senão desse modo ... É portanto consciência absolutamente universal. Esse ser

${ }^{8}$ Idem, I, p. 227.

${ }^{9}$ Idem, I, p. 228-230. 
suprassumido da totalidade singular (família) é a totalidade enquanto absolutamente universal, espírito (sociedade).... A totalidade singular e percebe a si mesma enquanto suprassumida, ser-ideal: não é mais a existência singular, mas a suprassunção de simesma e apenas é reconhecida enquanto suprassumida. Esta totalidade enquanto existência está posta em si mesma enquanto simplesmente possível, enquanto existência que não é para si e que apenas subsiste enquanto está sempre pronta a morrer, enquanto renunciou a si mesma. Existe enquanto totalidade singular, enquanto família com seus bens e seus gozos, porém de tal modo que esta relação é para si mesma uma relação ideal e se revela sacrificando-se a si mesma". ${ }^{10}$

A existência humana éa negação do ser-aí e a disponibilidade constante para uma morte voluntária. Todavia, não se trata de modo algum de uma propriedade misteriosa que introduz uma diferença metafísica entre o homem e a natureza. A liberdade é um constituinte: a negação do ser-aí natural define o ser da existência social como resultado do movimento mesmo da vida. A família que se apresenta como a última totalidade biológica, realiza igualmente a primeira forma da existência humana enquanto produz seus próprios meios de subsistência. ${ }^{11}$ Tal situação se revela como contraditória, pois se o trabalho faz surgir um mundo novo como negação da natureza, o Si permanece sempre sobre o plano do ser natural: eu pretendo guardar em minha posse o resultado de meu trabalho, porém esse resultado enquanto implica um sentido humano, encontra-se imediatamente cobiçado por todos. Se provoca um conflito onde o Eu afirmando seu ser singular, se nega nessa singularidade mesma e se põe como universal. Sendo produto universal, a apropriação d reconhecimento as relações singulares não são mantidas senão enquanto suprassumidas. $\mathrm{O}$ Ser enquanto suprassumido se afirma como ser social, no qual, o homem se realiza em sua verdade assumindo o sentido do mundo o qual ele produz. O indivíduo se eleva a universalidade enquanto sua existência mantem no sentido pelo qual ele é reconhecido e está sempre pronto a sacrificar sua vida para defender seu sentido. Não há verdadeira relação de posse senão a medida que tenha sido negado como simples relação de fato e posto como relação ideal de direito, na propriedade. O sujeito em sua existência social não é uma unidade biológica, mas uma pessoa definida em sua abstração como pura consciência de si negadora de todo o dado natural.

\footnotetext{
${ }^{10}$ Idem, I,p.230-231.

${ }^{11}$ Karl Marx, A Ideologia alemã, "Pode-se diferenciar os homens dos animais pela consciência, pela religião, pelo que se quiser. Começam eles mesmos a se diferenciar dos animais quando começam a produzir seus meios de subsistência.
} 
As figuras do espírito são as formas históricas de onde se constituem as relações propriamente humanas como a verdade na qual se absorvem as relações naturais enquanto reconhecidas em seu sentido de universalidade. Tal reconhecimento se define como passagem da economia à ideologia, posto que a atividade humana sobre o plano natural se define como atividade econômica. O homem não vive como o animal em simbiose com a natureza, senão cria um mundo distinto no qual consume aquilo que produz. O objeto econômico, enquanto negação do dado imediato implica um sentido de universalidade como disponibilidade universal. Resultado da atividade subjetiva, transforma por sua vez o sujeito, constituindo-o como sujeito universal. A vida econômica é o trabalho do negativo que eleva o Si a universalidade sobre o plano do real ou do em-si. O reconhecimento a essência social humana, como Si universal, define a dialética que faz passar o ser-para si do em-si ou a espiritualidade enquanto verdade da vida naural.

A exposição hegeliana explicita sobre o plano do conceito um movimento real cuja descrição correta apenas é possível no horizonte do materialismo histórico e dialético. As noções misteriosas de negatividade e de suprassunção desvelam seu sentido efetivo por referência ao desenvolvimento das forças produtivas; a abstração do conceito é quebrada pelo movimento de seu conteúdo real. Uma dialética deste gênero supõe que a vida econômica não é uma simples condição exterior da existência propriamente humana, mas a substância mesma de seu ser. A explicação materialista não é uma redução do espírito como vir-a-ser espírito da natureza ou vir-a-ser sujeito da substância. Na luta de vida ou morte, o homem se nega como natureza precisamente afirmando sua própria potência natural. Num tal movimento a existência se realiza em sua verdade: o desenvolvimento da produção material não é simplesmente o motor oculto da dialética da consciência, mas o fundamento de seu ser de verdade. O melhor modo de mostra-lo é examinar o movimento da Fenomenologia do Espírito.

\section{III}

Sem entrar no detalhe das figuras particulares da Fenomenologia se pode esboçar de modo relativamente simples o percurso geral do desenvolvimento. Avida humana se apresente, em primeiro lugar, enquanto relação do homem com a natureza, dito em outros termos, enquanto relação do eu com o objeto ou consciência do objeto. $\mathrm{O}$ conceito de economia definido as relações do homem com a natureza, a dialética da consciência (Capítulos I a III) constitui a exposição idealizada da história econômica da humanidade. Pela atividade econômica se elabora um mundo novo cujo significado 
propriamente humano se impõe como negação da vida imediata e afirmação de um modo mais elevado da existência. A História da humanidade revolucionária se apresenta como o vir-a-ser da consciência de si, na qual o Si refuta o mundo dado para por-se a si mesmo enquanto realidade verdadeira. As significações novas aparecem nas idades primitivas na existência singular mesma onde a luta de vida ou morte a relação de dominação ou servidão mediatizam as formas imediatas da vida social. Na antiguidade, as revoluções urbanas fazem triunfar a universalidade abstrata que define a civilização em sua luta contra a barbárie: o movimento se encerra com o estoicismo, o ceticismo e o cristianismo revolucionário (Capítulo IV). No período moderno, o indivíduo se afirma portando a universalidade em sua própria individualidade: a consciência de $\mathrm{Si}$, certa de ser toda a verdade, se apresenta como Razão (Capítulo V). A negação revolucionária do mundo dado finda com a tomada do poder e com a organização do mundo novo, especificamente humano, definido como mundo do espírito. O objeto é objeto universal elaborado pelo trabalho de todo e reconhecido pelo sujeito, ele mesmo universal, como sua própria realidade objetiva. A dialética do espírito exposta no Capítulo VI descreve o vir-a-ser da essência social humana enquanto universalidade efetiva. Porém, tal essência não se realiza plenamente senão pela consciência, no indivíduo, da verdade de seu ser como ser universal. Na consciência de si do Espírito, o Si toma consciência do sentido de sua existência enquanto sentido de eternidade. Este define o projeto humano que se encontra em primeiro lugar, representado exteriormente pela religião (Capítulo VII). Porém, o desenvolvimento histórico encerra-se num mundo que realiza plenamente sua universalidade em cada um dos seus momentos. O Si se reconhece na singularidade mesma de sua existência efetiva enquanto Si universal, no sabe absoluto (Capítulo VIII).

IV

O movimento da consciência compreende três momentos: certeza sensível, percepção e entendimento. A certeza sensível caracteriza a vida natural. Encontra sua significação "Nos mistérios de Ceres e de Baco, o segredo da absorção do pão e do vinho .... Os animais mesmos não estão excluídos desta sabedoria, senão que se mostram profundamente iniciados nela: pois não se colocam face as coisas sensíveis como se elas fossem em si, senão que desesperam dessa realidade e na absoluta certeza 
de seu nada, a tomam sem mais e a consomem e a natureza inteira celebra como eles estes mistérios revelados a todos, que ensinam qual é a verdade das coisas sensíveis". ${ }^{12}$

A certeza sensível é, pois, a relação do ser vivente com seu meio natural, na linguagem hegeliana, a relação imediata do eu singular com o objeto singular. Em sua forma original, implica a primazia do dado exterior, a atividade subjetiva não se apresenta ainda no nível senão por sob uma forma evanescente, como necessidade, busca e gozo: "O objeto é, a verdade e a essência; ele é, indiferente ao fato de ser conhecido; porém, o conhecimento não existe se não existe o objeto". ${ }^{13}$ Porém, declara Hegel que tal verdade se contradiz necessariamente a si mesma. Se queremos dizer o que é o objeto singular, advertimos que nossa definição é falsa posto que o objeto haverá mudada entretanto. Por mais forte que pareça o argumento, nãos e vê que pode tocar num espírito positivo. Poi, se é evidentemente impossível definir o aqui como tal, nada nos obriga a liberar-nos a uma operação desse gênero: a consciência natural não procede por definições, mas justamente por sensações o que a obriga a sair de si mesmo, mas ela apenas tem mostrado-se em si mesma. De fato, a potência do negativo somente pode ser encontrada mediante o exame do conteúdo real.

No estágio animal, a vida subjetiva é puro derramamento espontâneo e não pode organizar-se senão por relação ao dado exterior, assumido como um absoluto. Porém, o ser vivente, buscando satisfazer seus desejos, desempenha uma atividade que desenvolve-se naturalmente mediante o emprego do útil. Todavia, o útil é a materialização mesma da ação do Eu: "é isso em que o trabalho encontra sua permanência, isso que resta do sujeito trabalhador e do objeto trabalhado, nisso em que passam da contingência a necessidade" ${ }^{14}$. Seu uso regular cria um horizonte novo. O mundo não se impõe já como um dado absoluto, senão que se organiza em vista do $\mathrm{E}$, representando sob a forma real e consistente pelo útil. O Objeto não é mais o aqui tomado na apropriação imediata, mas todo existente em geral, enquanto que pode ser conseguido pela ação do útil. Seu sentido de ser se universalizou como pertencendo a um mundo desde já dominado pelo sujeito, que aparece imediatamente como realidade verdadeira. "O que permanece pela certeza sensível, não é senão o que nós vemos como ser, porém o ser com a determinação de ser a abstração ou o puro universal .... O Objeto que deve ser o essencial, é agora o inessencial da certeza sensível ... Isto passou agora

\footnotetext{
${ }^{12}$ Phänomenologie des Geistes, p.87, trad. Hyppolite, pp.90-91.

${ }^{13}$ Idem, p.81; I, p.83.

14 Jenenser Realphilosophie I, p.221.
} 
ao oposto, a saber, no saber que antes era o inessencial. Sua verdade é no objeto enquanto objeto meu ou em meu visar, ele é porque eu tenho um saber dele". ${ }^{15}$ Assumido como absoluto em sua singularidade o eu entrará numa nova dialética da qual será conduzido a negar-se enquanto tal. A constituição do útil permitirá suprassumir o estágio propriamente anima. A atividade subjetiva já não se define simplesmente mediante as formas biológicas, ela supõe uma aprendizagem através da tradição. Por sua vez, o objeto, mediado pelo trabalho não pode ser apropriado de modo imediato. No seio da horda surgem novos problemas, relativos as funções da educação, repartição, defesa, transmissão. A organização se elabora espontaneamente sobre o fundamento natural das relações familiares. A família se constitui em unidade social. Não é mais a comunidade natural imediata, mas uma comunidade espiritual definida mediante normas. A luta de vida ou morte na qual se compromete para a defesa de seu patrimônio, a coloca em seu ser ideal. O indivíduo se encontra suprassumido como eu singular e somente vive seguindo a lei universal do clã. No útil, a certeza sensível experimentou a universalidade do objeto, no clã, ela faz a experiência do $\mathrm{Si}$ como $\mathrm{Si}$ universal. "Quando enuncio Eu, esse Eu singular-aqui, enuncio de modo geral todos os eus: cada um dos quais é justo este que enuncio, eu, este eu-singular-aqui”. ${ }^{16}$

O aparecimento do clã no curso do mundo paleolítico faz surgir a humanidade propriamente dita sob a forma do selvagismo. O regime comunitário oferece um quadro favorável ao desenvolvimento das forças produtivas: mediante o trabalho familiar o mundo se constitui em mundo familiar. Nesse horizonte o real apresenta imediatamente um sentido para o eu. Enquanto este sentido não é entendido como um predicado exterior, mas integra o ser como seu próprio sentido, o objeto será a planta comestível ou o objeto domesticado. Pela agricultura e a pecuária, a comunidade familiar se constitui em totalidade natural bastando-se a si mesma. O sujeito e o objeto se confundem numa totalidade imediata: a família camponesa vive em comunidade com seus animais e suas plantações. "A certeza sensível faz a experiência de que sua essência não está nem no objeto nem no eu, e que a imediatez não é nem a de um, nem a do outro [...] chegamos deste modo a estabelecer o todo da certeza sensível mesma como sua essência, e não um apenas de seus momentos, como ocorria nos dois casos precedentes, onde em primeiro lugar estava o objeto oposto ao eu, e após o próprio eu devia ser sua realidade. É apenas a totalidade da certeza sensível que se conserva em si

${ }^{15}$ Phänomenologie des Geistes, p.82-83, trad. Hyppolite, I, p.85.

${ }^{16}$ Idem, p.83; I, p.86. 
mesma como imediatez [...] Sua verdade se mantém como relação que permanece igual a si mesma e que entre o eu e o objeto não há nenhuma diferença de essencialidade e de inessencialidade, e na qual, por consequência, nenhuma diferença pode penetrar". ${ }^{17}$

A constituição da agricultura e a criação de gado nos começos do neolítico fez passar a humanidade do estágio da selvageria ao da barbárie. O aparecimento da riqueza desencadeia a cobiça que faz surgir a guerra em estado permanente: os povos do neolítico criaram as fortificações. Com o hábito da competência, o Si se constituiu como pura negatividade abstrata se afirmou como tal nas luras por puro prestígio ${ }^{18}$, tal como o potlach. A igualdade primitiva desaparece nos conflitos perpétuos, que permitem a alguns indivíduos acumular riqueza e poder.

O clã comunitário é substituído pelo clã feudal com sua hierarquia de chefes, de homens livres e de escravos. A individualização da propriedade favorece o desenvolvimento da produção e da troca. O movimento de troca voltando-se sobre si mesmo enquanto totalidade se realiza na $\operatorname{moeda}^{19}$. Nesse movimento o mundo muda de sentido. O objeto já não é produzido para seu uso imediato, mas para a venda no mercado. Não é mais o aqui do gozo singular, senão a mercancia oferecida a todos e definida por caracteres válidos para todos. A produção se regula por normas abstratas, respondendo as necessidades postas em seu universal ideal. A relação de sujeito a objeto, mediatizada pelo dinheiro, se elevou à universalidade percebida em sua verdade: a certeza sensível passou à percepção.

A dialética idealista permanecendo ao nível das formas da consciência se encontra incapaz de fundá-las de modo efetivo. O motor do movimento da certeza sensível se apresenta em Hegel como o ato de designar o aqui e o agora mais que sai do aqui e do agora. Todavia, precisamente a consciência sensível não tem inquietudes desse gênero: se contenta com o sentir e permanece na imediatez.

De fato o sensível se suprassume na atividade sensível real. Em cada estágio do mundo primitivo, o trabalho humano retira o existente de seu ser imediato para integrálo num mundo novo, como mundo da verdade. Enquanto que o objeto produzido apresenta um sentido para o eu, será imediatamente o objeto de uma reflexão da consciência que buscará designá-la e nomeá-la. Na experiência da subjetividade surge

\footnotetext{
${ }^{17}$ Idem, p. 84; I, p. 87.

${ }^{18} \mathrm{Na}$ luta de vida ou morte cada combatente persegue a morte do outro e somente é uma consequência involuntária o pôr sua própria vida em perigo. Na luta por puro prestígio (potlach, hara kiri etc), se sacrifica voluntariamente para poder humilhar o adversário e demonstrar-se a si mesmo como superior a natureza: trata-se, pois de uma forma derivada, onde a consequência tornou-se o princípio.

${ }^{19}$ System der Sittlichkeit, in Schriften zur Politik und Rechtsphilosophie, pp. 440-444.
} 
um horizonte novo, de onde o se define pela universalidade, posto que somente o universal pode nomear-se. Porém, dito movimento supõe que o real se apresentou, já como um sentido que o retorna a nomeá-lo. A negatividade espiritual como reflexão da consciência nãos e exerce senão sobre o fundamento de uma negatividade real, como trabalho humano material. Não é precisamente senão a reflexão de Si sobre seu ser real e o universal percebido pela consciência expressa o universal já constituído, em si, no mundo material: e o ser-para-a-consciência desse em si.

Porém a Fenomenologia somente explicita a parte consciente desse movimento a única que que se manteve na memória da subjetividade. O mundo natural - o ser-aí foi no passado o objeto de um trabalho real que lhe deu um sentido em si. Herdeiro da história universal, o filósofo já não precisa ocupar-se de problemas materiais, já resolvidos: se contentará em repensar o vir-a-ser sobre o plano da consciência. "Dado que a substância do indivíduo e dado que o espírito do mundo teve a paciência de percorrer essas formas em toda a extensão do tempo e de empreender o prodigioso trabalho da história universal ... assim, consoante a coisa mesma, o indivíduo não pode conceber a substância por uma via mais curta; e não entretanto a dificuldade é ao mesmo tempo menor" ${ }^{20}$, visto que em si tudo isso realizou-se o conteúdo e a realidade efetiva já nihilizada na possibilidade ... sendo já uma coisa pensada, o conteúdo é propriedade (Eigentum) da substância, já não é o ser-aí que falta converter na forma do ser em-si, é apenas o ser em-si já não originário e também não oculto no ser-aí, mas presente na interioridade da memória que falta converter na forma do ser para si." ${ }^{21}$

Numa palavra, como enfatiza Marx "Hegel somente concebeu o trabalho como um trabalho espiritual abstrato". Considerando que a transformação efetiva do mundo real - a "conversão do ser-aí na forma do ser em-si - já foi obtida pelo movimento da história universal, o filósofo busca simplesmente enquanto indivíduo compreender como a consciência constitui para ela os sentidos já realizados, em si, no objeto. O vir-aser para a consciência do em-si tem como motora diferença, interior à própria consciência, entre o sentido explicitamente fixado do objeto e seu sentido implicitamente vivido, em si. No movimento da experiência o sentido vivido se impõe como o ser do objeto. Nessa objetivação, enquanto passagem da certeza à verdade, um objeto novo se revela à consciência: o mundo parece criar-se pela reflexão do Si acerca de si mesmo. Todavia, dita magia não é possível porque um longo trabalho material deu

\footnotetext{
${ }^{20}$ Sublinhado nosso.

${ }^{21}$ Phänomenologie des Geistes, pp. 27-28. Tradução de Hyppolite I, p. 27.
} 
previamente ao ser-aí o sentido do ser-em-si. "Justamente porque a consciência tem, de modo geral, o saber de um objeto, a diferença está já presente nela: para ela há uma parte do em-si, e de outra parte, o saber ou ser do objeto para a consciência. Acerca desta distinção, que se faz presente, se funda o exame. Se nessa comparação, os dois momentos não se correspondem, a consciência parece mudar seu saber para fazê-lo adequado ao objeto; porém a mudança do saber, muda igualmente o fato, o próprio objeto... Esse movimento dialético que a consciência exerce em si mesma, em seu saber assim como em seu objeto, enquanto que diante dela, o novo objeto verdadeiro saltando é propriamente o que se denomina de experiência." 22

O urgir da economia monetária fez passar a humanidade da barbárie à civilização. O mundo mercantilista é um mundo universal, sobre o movimento do qual se constituem as estruturas da racionalidade. "Tudo o que para a percepção, é o existente, é tomado por ela como Universal. Sendo a universalidade seu princípio geral são também universais os momentos que se distinguem nela: o eu como eu universal e o objeto como objeto universal" ${ }^{23}$. Contudo, somente se trata, desde já da universalidade imediata ou sensível que implica uma contradição entre a individualidade e a inteligibilidade. A produção antiga é uma produção artesanal, que se recente necessariamente do mundo natural sobre o qual se constitui. Somente consiste no introduzir na matéria trabalhada um certo número de propriedades abstratas independentes entre si; o objeto é "o meio no qual elas estão todas ... Nesse meio como numa unidade simples, elas se compenetram sem tocar-se...Dado que cada uma é uma simples relação a si mesma deixa as demais em paz e se relaciona a elas apenas pelo também indiferente. Esse também é o puro universal no qual o meio e a coisidade que os relaciona". ${ }^{24}$ Uma universalidade desse gênero permanece abstrata e não pode dar conta da individualidade do objeto que constitui não obstante sérum momento necessário. Pois para o artesão e o mercador somente trata de reunir um certo número de qualidades definidas, o interesse do consumidor se dirige sobre o existente em sua singularidade, como objeto de gozo ou unidade exclusiva: "O uno é o momento da

\footnotetext{
${ }^{22}$ Idem, p. 72-73; I p.74-75.

${ }^{23}$ Idem, p. 89; I, p. 93.

${ }^{24}$ Idem 91; I, p. 95-96.b
} 
negação enquanto se relaciona consigo mesmo de modo simples e exclui outra coisa" 25 . A oposição dos dois momentos se caracteriza no pensamento antigo "Somente há ciência do universal, somente há existência do singular" A solução somente poderia encontra-se na dialética da percepção como movimento histórico real.

O desenvolvimento da produção artesanal na antiguidade repousava sobre a exploração do mercado bárbaro que assegurava grandes proveitos necessários para incitar aos investidores e proporcionava a mão de obra servil. Entretanto, a prática do comércio colonial conduzia a criação de novos centros de produção que entram em concorrência com os antigos, ao mesmo tempo em que a saída da barbárie restringia cada vez mais as possibilidades do proveito mediante o reabastecimento por escravos. $\mathrm{O}$ desenvolvimento da cidade faz surgir as condições de sua própria decadência. Suas instituições se fundem na crise imperialista e nas guerras que elas engendram. A economia urbana acaba por dissolver-se sob o império romano com a migração dos ofícios até o campo, de onde se integram ao sistema patrimonial. Nesta volta ao estágio agrícola, as aquisições da vida civilizada perdem seu valor de universalidade - como valor de troca - para integrar-se a título de simples objetos de uso à totalidade natural constituída pelo grande domínio: a percepção volta-se a certeza sensível. “o simples e o verdadeiro que eu percebo não são mais um meio universal, massa propriedade singular para si ... como esse pura relação a si mesmo, ela permanece sendo somente o ser sensível em geral, porém não tem mais o caráter da negatividade. E a consciência mediante a qual há um ser sensível, é somente o visar do aqui que saiu completamente da percepção e retornou sobre si mesmo."26

A dissolução das antigas formas fez surgir as condições do nascimento de uma civilização mais elevada. “O ser sensível e o visar do aqui repousam na percepção... mas não do mesmo modo que da primeira vez. Ele fez a experiência de que o resultado e a verdade desse ato de perceber são sua resolução ou a reflexão retornando o verdadeiro a si mesmo" ${ }^{27} \mathrm{O}$ retorno da civilização a vida agrícola imediata - "a reflexão retornando o verdadeiro a si mesmo - implica apesar da redução das mudanças, a manutenção dos resultados do movimento anterior; as técnicas artesanais, o uso da moeda, a extinção da escravidão. As cidades antigas se desenvolvem sobre o mundo natural da barbárie. A reconstituição na idade média da vida urbana e das formas de racionalidade, parte dos

\footnotetext{
${ }^{25}$ Idem, p. 92; I, p.96.

${ }^{26}$ Idem, p. 94; I, p. 98-99.

${ }^{27}$ Idem.
} 
fundamentos de uma economia monetária, postos como elementos universalmente adquiridos. O objeto se apresenta já implicitamente como objeto de troca e implica virtualmente o sentido da universalidade. Este se encontra representado em sua abstração pela dominação universal da Igreja. Em tal horizonte o trabalho só pode se desenvolver sob o modo do trabalho assalariado. O assalariado realiza o sujeito no objeto e o eleva a uma universalidade efetiva.

A liberdade do cidadão antigo funda-se na exploração do escravo, sua experiência vivida limita-se a singularidade do existente, por um lado, momento do Uno exclusivo assumido no gozo e por outro lado à universalidade abstrata necessária para executar as tarefas de direção. As formas são percebidas apartadas, separadas do trabalho real que as constitui em seu vir-a-ser efetivo. Uma ordem do senhor é suficiente para se impor à matéria. Representadas em sua idealidade elas se encontram separadas umas das outras e a produção que sobre elas se regula dificilmente supera o estágio das oficinas. $\mathrm{O}$ objeto fabricado assim define o verdadeiro enquanto percebido. A inteligibilidade é impotente para dar conta da individualidade.

Na idade média o homem livre da cidade é o homem trabalhador. Definido em termos de dinheiro a atividade objetiva se integra à universalidade constitutiva do objeto. A experiência de Si como Si universal se identifica com o processo real no qual se elaboram as formas ideais. O momento do gozo se apresenta no objeto como consumação determinada pelo salário e somente é o momento do movimento universal da mercadoria. Esta se constitui em totalidade racional como ciclo do capital e envolve todas as fases da vida econômica. O dinheiro se transforma em mercadorias que produzem elas mesmas outras mercadorias e se retorna ao ponto de partida. A mercadoria apenas o trabalho humano em ação ou realizada em seu resultado. O movimento do capital se objetiva na manufatura onde os momentos particulares se absorvem na inteligibilidade de um processo universal. $\mathrm{O}$ existente em sua singularidade somente existe em sua relação com os outros graças ao dinheiro que serve de denominador universal, essa relação se encontra determinada por um cálculo rigoroso. Os momentos contraditórios da coisa, o Uno exclusivo e a pura universalidade desaparecem na relação posta como constitutiva da objetividade do objeto. A racionalidade matemática se substitui pela inteligibilidade ainda imediata e condicionada das formas e qualidade sensíveis: a percepção transita ao entendimento. "De um só e mesmo ponto de vista o objeto é o contrário de si mesmo: para si enquanto é para outro e para outro enquanto é para si. É para si, reflexivo em si, é Uno; porém 
esse Uno para si e reflexivo em si é uma unidade com seu oposto, o ser para-outro ... É então que se apresenta a universalidade absoluta e incondicionada e é nesse momento que a consciência entra verdadeiramente no reino do entendimento" 28 .

A passagem da oficina a manufatura faz surgir o mundo capitalista moderno. No processo da produção capitalista o objeto se constitui pela objetivação da atividade humana num movimento estritamente racional. O real somente é realização da subjetividade, o Si reflexivo em si mesmo, o conceito como negatividade constituinte. Entretanto o sujeito somente é tomado como uma realidade exterior que não se reconhece a si mesmo. O mundo capitalista é o mundo da essência humana alienada: as relações são puramente humanas, mas sob a forma desumana do dinheiro. "Esse universal incondicionado que é, no sucessivo, o objeto verdadeiro da consciência, é não obstante objeto da própria consciência; não é ainda compreendido seu conceito enquanto conceito. As duas coisas devem ser distinguidas: a consciência sabe que o objeto retornou a si a partir da relação com o outro e tornou-se desse modo conceito em si; mas a consciência não é ainda para si-mesmo o conceito porque não se conhece a si esma nesse objeto reflexivo". ${ }^{29}$

O processo do capital aparece desde logo sob sua forma exterior como movimento real do dinheiro e da mercadoria. Esta se apresenta em sua variedade multiforme, aquele na unidade do puro ser para-si. $O$ valor se constitui numa volatilidade perpétua como a força universal que se distribui passando continuamente do Uno ao Múltiplo e do Múltiplo ao Uno. O dinheiro se exterioriza na diversidade das mercadorias e de suas metamorfoses na produção, pois retorna a si mesmo para retomar o mesmo circuito. ${ }^{30}$ "As diferenças tomadas em sua independência transitam imediatamente a sua unidade e sua unidade imediatamente a seu desdobramento e seu desdobramento por sua a redução a unidade. É esse movimento precisamente o que se chama força: um os momentos desta, a saber, a força como expansão das matérias independentes em seu ser é sua exteriorização: o outro momento, a força como ser-

\footnotetext{
${ }^{28}$ Idem, p. 99-100; I, p. 04-105.

${ }^{29}$ Idem, p. 103; I, p. 109-110.

${ }^{30} \mathrm{O}$ movimento é o seguinte: $\mathrm{A} \rightarrow(\mathrm{M} \rightarrow \mathrm{P} \rightarrow \mathrm{M}) \rightarrow \mathrm{A}$
} 
desaparecido dessas matérias, é a força que de sua exteriorização é refutada em si mesma ou é a força propriamente dita" ${ }^{31}$.

O movimento se apresenta em primeiro lugar sob seu aspecto real como investimento do dinheiro numa empresa e sua recuperação pela venda de produtos fabricados cada uma dessas operações se cumprem numa relação de troca entre um solicitante e um solicitado. Mas, o desenvolvimento das operações permitem o circuito se constituir em totalidade; as funções tornam-se recíprocas, o solicitado pode ser considerado como solicitante e vice-versa. "A diferença que encontra lugar entre os dois momentos e que faz com que um deve ser o solicitante e outro o solicitado, essa diferença se transforma numa troca recíproca de determinidades". ${ }^{32}$ Assim, a realidade aparece como puro trânsito, o dinheiro somente possui sentido em seu tronar-se mercadoria e a mercadoria em seu tornar-se dinheiro. As diferenças que aparecem no fenômeno exterior são absorvidas na unidade puramente inteligível do capital como puro vir-a-ser recíproco do dinheiro e da mercadoria. O movimento real se suprassume para elevar-se a verdade como conceito. "As duas forças existem enquanto essências sendo para-si, porém sua existência é um movimento de uma relativa a outra tal como seu ser é antes um puro ser-posto por um outro, a saber que seu ser é antes a pura significação do desaparecer ... A força como efetivamente real é unicamente na exteriorização que comente é a supressão de si mesma... Sem nenhum repouso os momentos de sua realidade efetiva, suas substâncias e seu moimento se fundem numa unidade sem diferença ... essa unidade é o conceito de força como conceito. A realização da força é assim, ao mesmo tempo, perda de realidade". ${ }^{33}$

O desenvolvimento do capitalismo moderno eleva a consciência a concepção de um universo inteligível de onde a pura relação matemática define o ser do existente. A intuição do mundo que inspira a física mecanicista se constitui sobre uma prática racional: o cálculo de elementos da empresa capitalista enquanto momentos do vir-a-ser objeto. Cumpre compreender esse processo não num sentido psicologista. As relações de produção não definem simples formas sociais no sentido em que elas seriam exteriores a própria realidade. O trabalho humano não se aplica por fora da natureza, enquanto o homem pertence à totalidade natural, sua atividade e apenas o momento mediante o qual a natureza trabalha sobre si. A forma da produção define assim a

\footnotetext{
${ }^{31}$ Idem, p. 105; I, p. 112.

32 Idem, p. 107-108; I, p. 109-110. O primeiro movimento define o capitalismo comercial: $\mathrm{A} \rightarrow$ $(\mathrm{M} \rightarrow \mathrm{P} \rightarrow \mathrm{M}) \rightarrow \mathrm{A}=(\mathrm{M} \rightarrow \mathrm{P} \rightarrow \mathrm{M}) \rightarrow \mathrm{A} \rightarrow(\mathrm{M} \rightarrow \mathrm{P} \rightarrow \mathrm{M})$

${ }^{33}$ Idem, p. 109-110; I, p. 117-118.
} 
forma esma do real enquanto se produz a si mesmo. Num movimento deste gênero é a constituição mesma das coisas que se revela à consciência. O Si é o ser refletindo sobre si mesmo, a reflexão é interior à substância, ela define o momento da subjetividade. Se a atividade humana fosse um movimento exterior à natureza não se compreenderia como as formas da consciência que se elaboraram poderiam ter um valor de verdade. O objeto constituído não corresponde necessariamente a realidade das coisas e sua universalidade seria relativa a organização social da qual se desenvolveu. Todavia, o porvir humano somente é um momento do devir total. A vida humana somente é o movimento mesmo do real em seu devir-verdade. Portanto, os valores que implicam se encontram plenamente fundados como valores autênticos. O Ser do objeto para a consciência define o ser do existente, dado que o devir do objeto para a consciência somente é o movimento mediante o qual o real se constitui para si-mesmo. É, logo assim perfeitamente absurdo querer separar o materialismo histórico como teoria psicológica do conhecimento do materialismo dialético como teoria filosófica do universo. $\mathrm{O}$ materialismo histórico não possui nenhuma relação com o psicologismo. A referência à economia somente é uma simples explicação empírica do curso da representação: não é justamente se não a separarmos artificialmente da filosofia materialista como concepção geral do mundo. Enquanto que ela se integra na dialética universal da natureza, a dialética das forma sociais assegura o movimento da consciência o seu fundamento transcendental enquanto fundamento de verdade. "Se o negativo aparece em primeiro lugar como diferença entre o Eu e o Objeto, é do mesmo modo a diferença da substância consigo mesma. $\mathrm{O}$ que parece produzir-se fora dela enquanto atividade dirigida contra ela, é em realidade sua própria operação e ela demonstra que é essencialmente sujeito". ${ }^{34}$

O capital é o puro inteligível, "o interior das coisas" que se revela ao entendimento mediante o movimento exterior do dinheiro e da mercadoria. Esta como jogo de forças é o fenômeno se desvelando como simples fenômeno, a realidade sensível negando-se a si mesma e absorvendo-se no universal. A existência humana implica a expressão das forças naturais como simples aparências e sua absorção no mundo da relação como mundo da verdade. O Si agora somente atua sobre si mesmo, ainda que sob a forma de um objeto ainda exterior: a essência social humana realizada em sua alienação. O capital "é a verdade para a consciência porque nele como no em-si

\footnotetext{
${ }^{34}$ Idem, p 32; I, p.32.
} 
tem ao mesmo tempo a certeza de si mesmo ou seu ser para-si, porém ela não é ainda consciente desse fundamento, porque o ser para-si que o interior deveria ter em simesmo, somente é o movimento negativo, porém, este é ainda para a consciência o fenômeno que desaparece posto como objeto, não é ainda seu próprio ser para-si" 35 .

O capital dado como realidade em si, se apresenta assim como a lei imutável dos fenômenos em movimento, "o fenômeno absolutamente em movimento torna-se a diferença simples ... Essa diferença se expressa na lei como imagem constante do fenômeno sempre instável. O mundo suprassensível é assim o calmo reino das leis" ${ }^{36}$. Mas, o movimento reaparece na ação do conteúdo real. O capitalismo absorveu a diversidade da vida humana num sistema de relações inteligíveis nas quais a realidade somente subsiste como a lei da mudança. Mas a realização da universalidade como puro valor de troca implica sua particularização na distribuição do capital em seus diferentes momentos. Sua existência como ura relação universal somente é o ato mesmo dessa distribuição. "Na coisa mesma com esse movimento nada de novo nasce" ${ }^{37}$ dado que a diferença posta se suprime imediatamente como diferença e retorna à identidade: um só e mesmo valor que se põe identicamente na unidade do capital e da diversidade desses momentos, como pura passagem recíproca da igualdade à desigualdade e da desigualdade à igualdade. Mas, isto é precisamente o puro passar mesmo, o movimento negado em sua forma natural reaparece no inteligível como puro movimento universal. "Temos aqui uma segunda lei cujo conteúdo se opõe ao que a princípio era denominado lei, a saber, a diferença permanecendo constantemente igual a si mesma, mas essa nova lei expressa o devir do desigual ao igual e o devir do igual ao desigual ... graças a este princípio, o primeiro suprassensível, o calmo reino das leis, cópia imediata do mundo da percepção, se converte em seu contrário ... Esse segundo mundo suprassensível é um mundo invertido". 38

A ciência social não é a simples negação da vida natural como supressão dos objetos sensíveis na universalidade abstrata do valor de troca, pois revela em seu conteúdo positivo como vida e movimento. Neste universal concreto, o primeiro universal aparece como um simples fenômeno que se absorve em sua verdade. "Assim o interior é realizado enquanto fenômeno. Mas, o primeiro mundo suprassensível era apenas a elevação imediata do mundo da percepção no elemento do universal. Tinha seu

\footnotetext{
${ }^{35}$ Idem, p. 111; I, p. 120.

${ }^{36}$ Idem, p. 114; I, p. 123-124.

${ }^{37}$ Idem, p. 119; I, p. 129.

${ }^{38}$ Idem, p. 120-121; I, p. 131.
} 
origem necessária nesse mundo da percepção, o qual retinha para si-mesmo o princípio da mudança e da alteração; o primeiro reino das leis não possuía esse princípio, obtendo-o agora enquanto mundo invertido" 39

O objeto produzido pelo trabalho humano apresenta um sentido de universalidade como sentido humano que implica por parte do sujeito uma apropriação ela mesma universal. Um bem enquanto tal é necessariamente o objeto da cobiça de todos e a posse somente é efetiva se encontra-se reconhecida por todos. Na existência ainda natural das idades primitivas o reconhecimento somente se obtém mediante uma luta de vida ou morte. Com a constituição da economia monetária e as estruturas de universalidade um mundo novo aparece como mundo civilizado onde a vingança privada dá lugar ao castigo aplicado pela autoridade social. De fato a sociedade se realiza como o ser próprio do indivíduo: no castigo é o criminoso que se suprime a si mesmo em seu ser natural para se restabelecer em sua essência universal. Mas, a operação somente se apresenta de modo exterior e formal como sanção jurídica. Somente realiza sua verdade no mundo moral, onde a penitência produz a reabilitação efetiva. A economia monetária absorveu as relações naturais imediatas numa universalidade abstrata enquanto legalidade formal. Assim se revela que a negação da vida espontânea é a constituição de uma vida mais elevada. A universalidade não é simples inteligibilidade imóvel: define a natureza nova como modo novo da existência. "segundo a lei imediata, a vingança contra o inimigo é a mais alta satisfação da individualidade ultrajada. Mas essa lei - segundo a qual devo mostrar-me, como essência, frente a quem não me trata como essência autônoma e, antes, suprimi-lo como essência, - se converte através do princípio do outro mundo no oposto; e a restauração de mim mesmo como essência, mediante a supressão da essência alheia, se converte em autodestruição. Porém, se for erigida em lei essa inversão - que é representada no castigo do crime - será também de novo apenas a lei de um mundo que tem como sua contrapartida um mundo sensível invertido, no qual se honra o que no outro se despreza, e onde é ignomínia o que no primeiro é honra. O castigo, que segundo a lei do primeiro mundo desonra e destrói o homem, transmuda-se, em seu mundo invertido, no perdão que salvaguarda sua essência e o leva à honra." 40

Convém evidentemente ao fazer do mundo moral um mundo separado, o que nos faria recair nas oposições abstratas: não é senão o primeiro mundo eu se desdobra nele

\footnotetext{
${ }^{39}$ Idem.

${ }^{40}$ Idem, p. 122; I, p. 132-133.
} 
mesmo. O desdobramento se operou sobre o plano religioso ao final do desenvolvimento antigo que somente realizou a universalidade de modo imediato. $\mathrm{O}$ capitalismo moderno que penetra na substância mesma do ser exige uma revolução real. A identidade do indivíduo e da totalidade social implica na alienação do ser humano num processo de cisão interior que é imediatamente retorno a si. A vida humana somente é a atualização da essência universal somente existindo a vida humana em sua realização na consciência singular de si. O Si se eleva a universalidade num mundo que é puramente humano. Nesse movimento a forma da exterioridade o objeto entra em contradição com seu conteúdo real. Este se revela como verdade da vida efetiva numa tomada de consciência revolucionária onde as relações alienadas se negam em sua alienação para afirmar-se em sua significação propriamente humana, como pura interioridade e universalidade vivida. O sujeito acaba elevando-se da atividade econômica à consciência política. $O$ mundo se reverte desvelando-se como idêntico a si e a consciência, enquanto consciência do objeto, torna-se consciência de si.

\section{VI}

Este trabalho não pretende examinar todas as figuras da Fenomenologia. Um comentário geral será necessário para explicitar todo o sentido do movimento. Queremos apenas indicar com alguns exemplos o método que seria conveniente aplicar. O caráter severo com que Kojève condena o erro monista de Hegel reclama estes esclarecimentos. O conceito de identidade das contradições define o fundamento mesmo da dialética. Defendendo o dualismo, mesmo que com um estilo brilhante, Kojève se coloca deliberadamente fora do horizonte hegeliano

A concepção de história como realidade suprema perde ao mesmo tempo sua significação efetiva. A separação absoluta entre o homem e a natureza desagua praticamente numa nova forma de espiritualismo que deixa a porta aberta a um retorno ofensivo da religião. Ninguém nega ou discutir o ardor e a solidez das convicções ateias de Kojève. Não obstante, não fica claro que resposta decisiva poderia se opor as interpretações modernas que fazem do cristianismo uma religião da imanência, segundo R. P. Niel "A ideia de humanidade-Deus desenvolvida por Hegel implica uma ruptura com a teodiceia tradicional, não com a fé em Deus....O Dualismo não está necessariamente ligado a fé em Deus. O cristão assim como o existencialista ateu e o comunista, enxerga na história a realidade última. Ela é para ele a categoria suprema. ... 
O Deus dos cristãos não é o deus de Aristóteles, mas Jesus de Nazaré". ${ }^{41}$ Com todas as reservas feitas acerca da ortodoxia destas declarações é bem claro que elas mantêm o essencial da religião. Nada se deve temer de uma filosofia da história que apresenta a subjetividade humana como um absoluto separado da natureza e re-introduz por isso mesmo um elemento de transcendência, quase nada falta para um apologista sutil. A oposição se reduzirá uma querela de teologia om os tomistas, "É possível, diz R. P. Niel, dissociar a fé em Deus de um certo teísmo racionalista saído da teologia aristotélica. Certamente o pensamento hegeliano tem sido gerador de ateísmo, porém é por ter sabido realizar o Eritis sicut dii das Escrituras, por haver reconstituído uma ciência do Todo. O grande mérito da filosofia da existência foi mostrar justamente que não existe ciência possível do Todo.... Aqueles que renunciam a buscar para sua fé um refúgio na Ideia e veem na história a realidade última não terão dificuldade em reconhecer em Jesus de Nazaré a realização concreta desta totalidade"42.

De fato, a ambiguidade vem de que o problema tem sido posto no terreno metafísico de onde não pode manifestamente chegar a nenhuma solução válida. Apenas tem sentido perguntar-se se o absoluto é humano ou divino, esta é a questão de definição e, ademais, o conceito de Homem-Deus permite salvar tudo, nominalizando o equívoco.

Igualmente não haveria nenhum proveito em buscar se o real é matéria ou espírito, entendendo por isso uma matéria que somente seria matéria e um espírito que somente seria espírito, pois é por demais evidente que não doeria ser exclusivamente nem um, nem outro. E seria perfeitamente desastroso deduzir que a totalidade é matéria e espírito, dado que haveríamos feito senão batizar a dificuldade. A unidade verdadeira não pode encontrar-se nem no plano abstrato de uma redução arbitrária, nem no plano eclético de uma justaposição sem conceito. Ela somente se realiza mediante a passagem de um dos termos em seu oposto. Assim, o verdadeiro problema não é metafísico, mas dialético, não concerne à natureza do ser, mas ao sentido do devir. Trata-se e saber se o movimento se faz de baixo para cima ou de cima para baixo, se o após é produzido pelo antes ou se tem necessidade, pelo contrário, de um princípio transcendência, Deus, Ideia ou Liberdade, no sentido da liberdade de indiferença. No primeiro caso a natureza torna-se espírito por uma dialética que lhe é própria e cuja necessidade enquanto imanente define o conceito autêntico de liberdade. No segundo caso a noção de espírito

41 "L'Interpretation de Hegel" in Critique, nov. 1947, p. 433-434.

42 Idem, p. 436. 
realizando-se no mundo nós fará retornar, por um caminho ou por outro, as representações ancestrais resumidas no mito da Encarnação. Desde esse ponto de vista o equívoco já não é possível: a essência das coisas pode parecer híbrida, o movimento somente possui uma direção.

Estas considerações não devem diminuir o valor singular do trabalho de Kojève. Sua interpretação tem o mérito de ser correta, precisa e de aprofundar no conteúdo. Ela apresenta em sua interioridade os problemas que surgem do espírito do mundo no estado atual do desenvolvimento, apresentando-se, por esta razão como um dos momentos axiais do vir-a-ser do Espírito absoluto. 